\title{
Analysis of Young Generations toward Stock Investment Intention: A Preliminary Study in an Emerging Market
}

\author{
Bagus Aditya Nugraha ${ }^{1 *}$ and Raden Aswin Rahadi ${ }^{2}$
}

\begin{abstract}
:
Research aims: This study attempts to analyze the young generations' perceptive variables in Indonesia, namely millennial (generation $\mathrm{Y}$ ) and generation $\mathrm{Z}$ toward stock investment intention preliminarily.

Design/Methodology/Approach: This study posits perceptive variables from the Theory of Planned Behavior (TPB) with various demographic characteristics as tablemoderating variables. This study utilized a structured online questionnaire survey to collect 64 samples and being analyzed by PLS-SEM. The group differences that being examined were investigated with multi-group analysis. Research findings: The findings from this study revealed that not all perceptive variables from TPB were significant on young Indonesian generations toward stock investment intention; only attitudes toward behavior had a significant effect. These findings were contrary to prior literature. Besides, Indonesia's young generations' education level also played a moderating role in influencing stock investment intention.

Theoretical contribution/Originality: This preliminary study provides potential facts regarding the applicability of the Theory of Planned Behavior in the emerging market (Indonesia) in stock investment intention.

Practitioner/Policy implication: The practical contribution would be insights for policymaker and Securities Firms regarding young generations' perspective on stock investment and what possible actions in terms of policies, programs, and campaigns that need to be done to increase the growth of investors' number in Indonesia. For public firms, the insights could be useful in constructing sustainability strategies in terms of funding source from the firm's stock. Research limitation/Implication: The sample used for this preliminary study was restricted to young generations divided into generation $Y$ and $Z$ from Indonesia only. This study focused on the fundamental implementation of TPB only; hence, the individual behavioral intention analysis was limited to TPB proxies. Since an online survey using a questionnaire was used to collect the data, the findings were limited and depending on the respondents' answers regarding the issue. Keywords: Stock Investment Intention; Theory of Planned Behavior; Young Generation; Partial Least Square
\end{abstract}

\section{AFFILIATION:}

${ }^{1,2}$ School of Business and Management, Institut Teknologi Bandung, Bandung, West Java, Indonesia

*CORRESPONDENCE:

Bagus-aditya@sbm-itb.ac.id

THIS ARTICLE IS AVAILABLE IN: http://journal.umy.ac.id/index.php/ai

DOI: 10.18196/jai.v22i1.9606

Nugraha, B. A., \& Rahadi, R. A. (2021). Analysis of young generations toward stock investment intention: $\mathrm{A}$ preliminary study in an emerging market. Journal of Accounting and Investment, 22(1), 80-103.

\section{ARTICLE HISTORY}

Received:

23 Aug 2020

Revised:

26 Oct 2020

07 Nov 2020

09 Nov 2020

Accepted:

25 Nov 2020

\section{Introduction}

In the realm of behavioral finance, most literature has only focused on how investors maximize their decision-making to generate more returns with minimum numbers of risk (Barberis, Shleifer, \& Vishny, 1998; Daniel, Hirshleifer, \& Subrahmanyam 1998; Fama, 1965; Lintner, 1965; 
Statman, Thorley, \& Vorkink, 2008). To complete the knowledge development in this field, internal factors examination was ever done as well to find its correlation with the investment decision-making process, for instance, between investors' demographic characteristics (age, gender, education level, and experience) and their investment decisions through behavioral factors (sentiment, over-confidence, over-reaction, underreaction, and herd behavior) as moderating variables in the Egyptian stock market (Metawa, Hassan, Metawa, \& Safa, 2019). Moreover, behavioral factors, such as sentiment, were used to examine investment decisions towards Islamic occasions (Jaziri \& Abdelhedi, 2018).

Besides those studies above, only a few research studies used behavioral factors to study someone's intention toward investment itself. Recent literature demonstrated that behavior, subjective norm, perceived behavior control, and attitude influenced investment intention (Luky, 2016; Phan \& Zhou, 2014). Several distinct works of literature have been published, which revealed that psychological and emotional factors had influences on investors' decision to invest (Griffith, Najand, \& Shen 2020; Lo, Repin, \& Steenbarger, 2005; Statman et al., 2008). According to Lai (Lai, 2019), in which studied the effect of an individual's personality traits on a stock investment by examining investor's intention, all stakeholders involved, like the government as the policymaker and managers of security firms, would have a better picture about how to encourage people awareness regarding stock investment effectively with better regulations, campaigns or programs, and services (security firms). In short, studying people's intention to involve in any investment activity must have several good implications, such as improving the national economy level. Moreover, a study regarding people's intentions will help all stakeholders like the capital market and securities companies to attract more people to participate in the market. In other words, it might be useful as well to boost the growth of investors' numbers in a country, especially in a country with an emerging market like Indonesia.

Indonesia's capital market, or known as the Indonesia stock exchange (IDX), was established in 2007 to be a party that organizes and provides the trading system. Even though it has only a short period in terms of the milestone, IDX has already performed as it should be as the capital market and plays a significant role in the national economy (Mardiyati \& Rosalina, 2017). IDX also creates several programs intended to raise understanding of economics and, in a way, to boost public confidence to invest in the Indonesian stock market. Two of them are Yuk Nabung Saham (YNS) and Galeri Investasi Bursa Efek Indonesia (GI-BEI). YNS was initiated in 2015 and aimed to change the habits of Indonesian people who initially saved money conservatively to invest; thus, Indonesians began to move from saving oriented society to investing oriented society (Sari \& Mayasari, 2017). Savings with investment orientation would educate investors to learn and generate profit to prepare for the future (Kiyosaki \& Lechter, 2001).

As was mentioned earlier, YNS is not the only program initiated by IDX to introduce investment knowledge and capital market to Indonesian people. IDX has been working over the years with many securities firms and universities in Indonesia to establish GI$\mathrm{BEI}$, specifically initiated for academia and the broader community as this program's 
target (Sari \& Pradana, 2018). The purposes of the GI-BEI program are to be a shelter for information and socialization center and be an educational facility and a bunch of activities, such as investment practices and real-time analysis of information related to capital markets. As stated in Figure 1, GI-BEI has been one of the long-standing programs initiated by the IDX since 2000 and has successfully established 410 galleries in 2018 (Otoritas Jasa Keuangan, 2019).

Nevertheless, despite all the efforts initiated by IDX, investors' numbers are still relatively slow. According to Kustodian Sentral Efek Indonesia (KSEI) in Figure 2, the growth of investors' numbers in Indonesia has not shown increase significantly, referring to the number of Securities Sub Accounts at C-BEST from KSEI as of July 2020, which only $1,603,232$ accounts (Kustodian Sentral Efek Indonesia, 2020). Suppose compared with the Indonesian population per 27 April 2020, in which of 273,013,347 people (Worldometer, 2020), the percentage of investors did not reach even one percent of the population. On the other hand, other countries have exceeded at least ten percent of their total population, such as Malaysia and Singapore (Saraswati \& Wirakusuma, 2018).

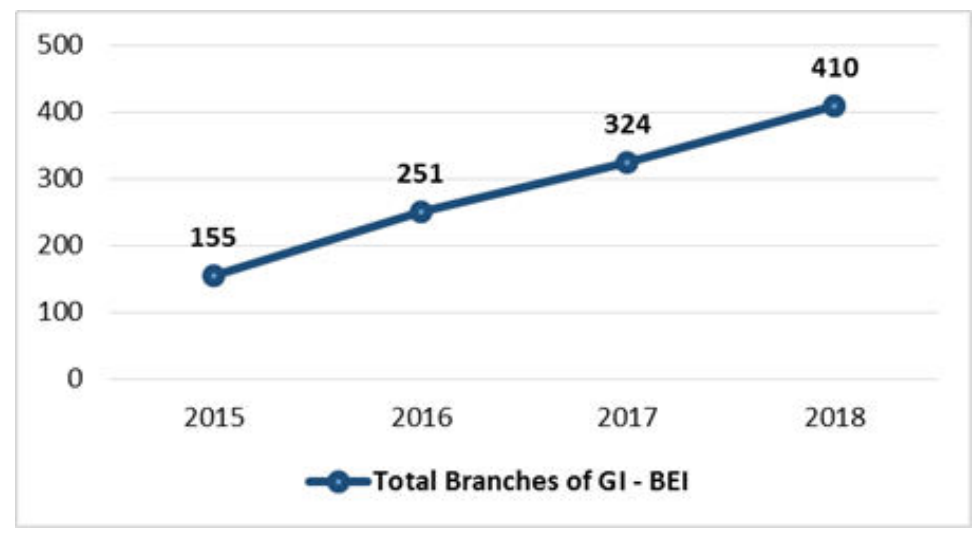

Figure 1 Total Branches of GI - BEl in 2015 - 2018

Source: www.ojk.go.id

Regardless of investors' growth, the potential domination of generation $Y$ and $Z$ as investors in the market is exciting to be discussed. According to IDX, most Indonesian capital market investors were dominated by generation $Y$ and $Z$ under 30 years old, reaching around 40.33 percent, followed by 29.55 percent of Generation X, who were approximately 31-60 years old in 2019 (Kencana, 2019). This dominance is very promising in terms of improving financial inclusion and financial literacy level in Indonesia. Furthermore, these two generations will dominate the structure of Indonesia's population in the following years in the demographic bonus or demographic dividend condition (Badan Kependudukan dan Keluarga Berencana Nasional Keluarga Bahagia, 2017). Thus, it needs to be maintained to increase the growth of investors' numbers and maximize the demographic dividend. 
Analysis of Young Generations toward Stock Investment Intention: ...

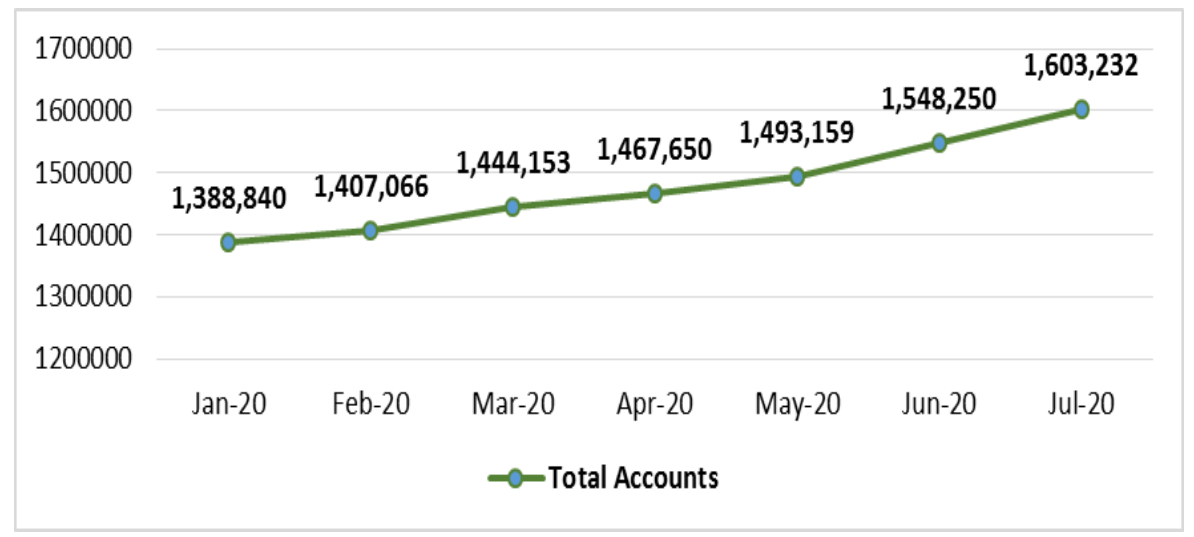

Figure 2 Total of Securities Sub Accounts at C-BEST (January 2020 - July 2020) Source: www.ksei.co.id

To contribute to the area of behavioral finance, the authors decided to examine Indonesia as one of the developing countries with a short history of its capital market, which has several problems regarding its growth of investor's number compared to the population. With all these motivations and phenomena, this preliminary study's authors are intended to find an alternative way of improving generation $Y$ and $Z$ 's investment intention by utilizing the Theory of Planned Behavior by Ajzen (1991). This study is the first attempt to specifically examine generation $Y$ and $Z$ 's perspective on stock investing. The examination of demographic characteristics as moderating variables is expected to provide new insights regarding young generations in emerging countries.

This preliminary study's practical contribution would be insights for all stakeholders involved in understanding the young generations, including their perspectives toward stock investment, both of which have been participated in the market and have not been tried at all. The insights potentially help the stakeholders about what possible actions in terms of regulations, programs, and campaigns, which need to be carried out in increasing the growth of investors' number in Indonesia. The findings can help public firms manage their sustainability strategies in terms of funding source from the firm's stock because they will know exactly how to attract young generations with their annual report or General Meeting of Shareholders.

Relevant literature associated with the hypotheses and proposed model framework is discussed in section 2 within this research paper. Then, it is continued with the research method in section 3. Section 4 describes the results and discussion before it was concluded in section 5 and the implications and recommendations for future researchers.

\section{Literature Review and Hypotheses Development}

The theory of planned behavior (TPB) was introduced as a social psychology theory that explains human behavior (Ajzen, 1991). However, firstly, it was developed from the 
theory of reasoned action (TRA), established in 1975 by Fishbein \& Ajzen (1975). In TRA, the intention is one of the most dominant constructs in influencing a person's behavior; intentions themselves can serve as observational parameters for behavioral tendencies, such as what individuals will do. In the intention spectrum, two things can determine the reasons or causes of the "intention": attitudes and subjective norms. Even intention can provide a cognitive picture of a person's behavior (Fishbein \& Ajzen, 1975). As a more straightforward explanation related to the application of this theory, there are two fundamental tendencies for one's intention to do something; if not caused by external impulses, those tendencies must come from the individual himself (Azwar, 2013). The inherent sense judgment allows an individual to give his/her assessment of what he/she will do, whether it is suitable for him/her, provides benefits, or because of the things that will be done in the process.

As said earlier, TRA has developed in explaining the new phenomena that have evolved along the way. The development process results in a new theory explaining the relationship between one's intention and behavior more in-depth, called TPB (Ajzen, 1991). As shown in Figure 3, in TPB, perceived behavioral control is added as a new factor or construct to explain one's intentions comprehensively (Lai, 2019). The addition of this construct is intended to overcome the limitations and lack of resources used by someone in behaving (Panggalih \& Baridwan, 2012). The emergence of new theories can further explain the influence of one's intentions in behavior, based initially on the level of human rationality, which always filters the information available to him; then, systematically measures the impact that may occur on individual decisions to behave (Luky, 2016).

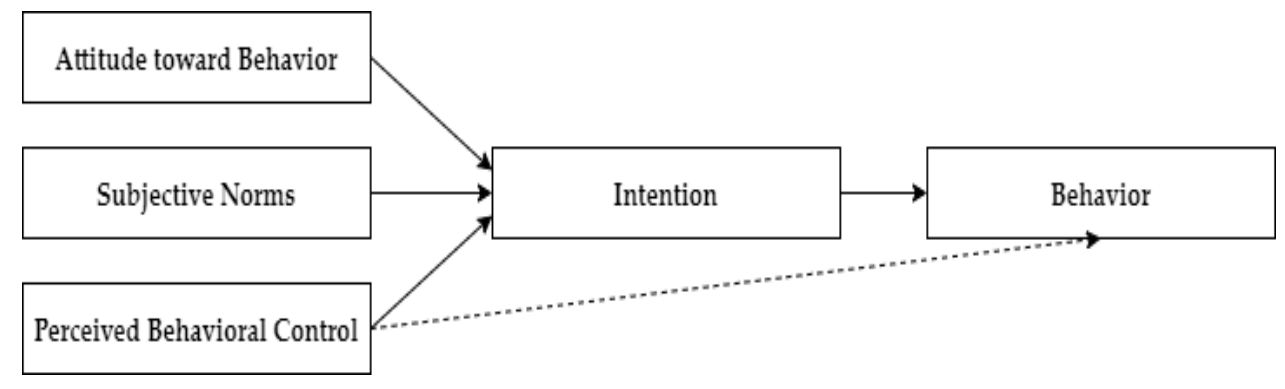

Figure 3 Theory of Planned Behavior Source: Azjen (1991, p. 182)

Once TPB was proposed, multiple studies were published and applied TPB as the grand theory in terms of its several implications. TPB once elaborated with consumer's behavioral intention toward sharia mutual funds (Octarina, Hartoyo, \& Beik, 2019). Moreover, a study about how an accountant practitioner behavior from TPB perspective on managing the firm's earnings has also been conducted (Yen, Chang, \& Wu, 2016). Furthermore, in the context of stock investment, those TPB proxies were found to have a significant influence in explaining individual investment intentions (Lai, 2019). In another context of stock investment, someone would be happy to participate in activities, such as seminars and workshops related to investment, learn about investment offers, or do anything that can support one's investment activities, if 
someone already has an intention to it (Situmorang, Andreas, \& Natariasari, 2015). In constructing the TPB hypothesis toward investment intention, the authors decided to focus on three proxies from planned behavior theory as perceived constructs based on prior literature, including attitude toward the behavior, subjective norm, and perceived behavioral control. Therefore, the hypotheses developed for the theory of planned behavior on stock investment intention would be described.

Literature in reasoned action defines attitude as an evaluative effect of individual positive or negative feelings towards the conduct of a specific behavior (Fishbein \& Ajzen, 1975). Nevertheless, conduction purpose is recently described as the favorability or unfavorability of the person to psychological objects (Fishbein \& Ajzen, 1975). This proxy can be utilized to evaluate how behavior is determined by attitude (Elliott \& Ainsworth, 2012). Hence, if a person has a better attitude to a particular action, he is more likely to want to perform the activity (O'Connor \& Paunonen, 2007). It is reasonable to conclude that, in the investment context, if an individual investor is more favorable to the investment, it can be more attracted than less inclined. ATB positively affected an individual's investment intention (Lai, 2019; Phan \& Zhou, 2014). Moreover, a positive and significant influence from ATB on investment intention was also found in Robert East's work (East, 1993). Within this current study, individuals referred to people categorized as generation $\mathrm{Y}$ and $\mathrm{Z}$ in Indonesia. The hypothesis was defined:

$\boldsymbol{H}_{1}$ : ATB has a positive influence on stock investment intentions.

One of the two initial TRA concepts is the subjective norm. It incorporates people's perception of whether the rest of others feel their actions to be essential or not. SN describes how social pressure from external parties (important to an individual) matters for individual behavior decisions (Elliott \& Ainsworth, 2012). They let others' opinions influence their actions (Fishbein \& Ajzen, 1975). According to TPB, if someone, i.e., individual stock investors, discovers that those who are more important to him or her feel they should be behaving, they will most likely do so (Mardiyati \& Rosalina, 2017). If an individual investor experiences the $\mathrm{SN}$ effect, his investment intention is higher than those that do not feel the same way (Lai, 2019; Phan \& Zhou, 2014). In other words, SN can be defined as a pressure felt by someone and potentially determine behavior in the form of intention. Therefore, the hypothesis was constructed as:

$\boldsymbol{H}_{2}$ : $\mathrm{SN}$ has a positive influence on stock investment intentions.

For further discussion of ATB and SN based on the experimental conducted; apparently, ATB and SN were proven to have a relationship (Fishbein \& Ajzen, 1975). Moreover, much literature also found that SN had a significant effect on ATB. In the context of green hotel customer intention in the United States, SN to ATB significantly influenced visit intention (Han, Hsu, \& Sheu, 2010). Moreover, SN to ATB significantly contributed to the prediction model regarding tourist intentions to experience local cuisine (Ryu \& Jang, 2016). The relationship between SN and ATB also provided a significant 


\section{Nugraha \& Rahadi \\ Analysis of Young Generations toward Stock Investment Intention: ...}

improvement in model fit in predicting unethical behavior (Chang, 1998). Therefore, in the context of young generations' analysis toward stock investment intentions in Indonesia, the authors decided to observe potential social pressure on those generations' attitudes in participating in stock investment. The hypothesis is described as follows:

$\boldsymbol{H}_{3}: \mathrm{SN}$ has a positive influence on the ATB of stock investment intentions.

Perceived behavioral control represents the control belief in TPB. The PBC framework was introduced to address the TRA model weaknesses and be used when people are not adequately controlled by several owned resources to conduct a specific behavior (Ajzen, 1991). Azjen defines PBC as an individual's perception of the ease or the difficulty in performing a specific behavior. In other words, within the TPB model, the stronger one's $\mathrm{PBC}$ is, for instance, an individual investor, the more likely he would conduct the behavior (Ajzen, 1991), and vice versa, the chances would be less. Consequently, the behavior performance is correlated with one's confidence in their ability to conduct the behavior (Sheeran, Trafimow, \& Armitage, 2003). Individuals with higher PBC were predicted to have more investment intention than individuals with a lower PBC intention (Lai, 2019; Mahastanti \& Hariady, 2014; Phan \& Zhou, 2014). Therefore, within this preliminary study, it is expected that young generations with greater PBC would be more potential to have stock investment intention. The hypothesis was defined as:

$\boldsymbol{H}_{4}: P B C$ has a positive influence on stock investment intentions.

If a person voluntarily does something contradictive to what he or she specialized with high effort, even if he or she does not know anything about it in the first place, it can be concluded that he or she has a high interest or intention in something. It is consistent with the intention definition put forward by Slameto (2003); the intention is defined as "a form of acceptance of a relationship between a person and something outside of himself"; the higher the interest generated, the stronger the relationship of a thing outside one's self with him/herself (Slameto, 2003). Referring to stock investment, a person's intention level in investing can be measured through his persistence in learning all aspects of investment and practicing it even though he must sacrifice his time and energy. Someone who has a high interest in investing will tend to find out many things related to the investment itself, such as investment type, the benefits, and risks that may be obtained.

Other than that, conducting analysis related to investment performance and how someone can start investing their activities, including considering the firm's financial position evaluations, can also show someone's intention level on stock investment (Keller \& Siegrist, 2006). Moreover, individuals' pre-action in showing their intention on stock investment and personality traits also play significant roles in influencing someone's intention to start investing their money into the capital market (Lai, 2019). East illustrated that friends' suggestions and funds owned affected someone's 
investment intention (East, 1993). Another side, overconfidence, optimism, herd behavior, and risk attitude belonged to psychological factors used to examine investment intention in the Vietnamese Stock Market (Phan \& Zhou, 2014).

Mannheim introduced generation-related theories in the scientific realm. In his essay entitled The Problem of Generation, he argued that as the times evolve, humans will influence one another and form distinctive characters (Mannheim, 1928). One example presented was that humans who lived before the Second World War would have a different character than humans who lived after World War II. However, the differences that occurred could not argue that the humans' character who lived after the Second World War grew due to the influence of humans who lived before the Second World War. Through this theory, prior researchers divided humans into several different classifications based on the time of birth, starting from the Generation of Depression Era, World War II Generation, Post-World War II Generation, Baby Boomer I Generation, Baby Boomer Generation II, Generation X, Generation Y (Millennial), then Generation Z. Besides age that distinguishes between each generation, there are other comparisons, such as how to communicate, spend money, and use free time (Birchmore \& Kestle, 2011).

Referring to this study's background, only two generations were explored by the researchers. Generation $Y$, or known as the millennial generation, is individuals born around 1980-ends of the '90s, while generation $Z$ is born around 2000 until now (Birchmore \& Kestle, 2011). These two generations certainly have different core values, and it can be realized with the different times faced. As an example, the problem of technology for communicating; logically, of course, generation $\mathrm{Y}$ will value communication more directly compared to being mediated with technology because they are used to it before the rapid development of technology in the field of communication. On the contrary, generation $Z$ has been exposed to technological developments since they were born; in the context of communication, they will feel more effective and comfortable if the conversation takes place through technology intermediaries. Another example is the perspectives of generation $\mathrm{Y}$ and $\mathrm{Z}$ that are very different in dealing with money. For generation $Y$ they are looking for money to be used directly. Unlike the generation $Z$, who tend to spend on something, they consider having more value to support their lives. Besides, there are still many that can become a comparison between these two generations. In this paper's context, what was examined was the comparison of these two generations to investment intention (Birchmore \& Kestle, 2011).

Following the Law of the Republic of Indonesia No. 40 the year 2009 regarding Youth, besides differences between generation $Y$ and generation $Z$, these two generations are represented as young generations. Therefore, regarding this preliminary study's background, young generations' analysis toward stock investment intention focused on the two generations. Moreover, this study tried to utilize several demographic characteristics from these two generations as moderating variables. The chosen moderating variables were intended to know how those demographic characteristics affected the strength of the relation between perceptive variables and behavioral 
intention from young Indonesian generations toward stock investment. Those moderating variables included ages (AGE), gender (GDER), an education level (EDU), occupation (OCUP), income source (INCS), income level (INCL), investment experience (EXP), and financial literacy (FLIT).

Those variables above were adopted from several prior studies. According to Lai (2019), AGE and EXP were significantly influenced by PBC, while GDER was found to significantly influence moderating ATB (Lai, 2019). In line with Lai (2019), GDER played moderating roles in the relationship between ATB, SN, PBC, and SII (Phan \& Zhou, 2014). GDER would help us in diversifying the respondent as well (Barber \& Odean, 2000). In this context, EDU and OCUP were applied to give a better spectrum in explaining respondents' profile (Akhtar \& Das, 2019). Moreover, AGE, GDER, and EDU were also once used to evaluate investors' decision-making in the Egyptian Stock Market; those demographic characteristics were found significant in moderating investors' decisionmaking process (Metawa et al., 2019). AGE matters, especially in terms of decision (Morris \& Venkatesh, 2000). INCL was once found to be significant in behavioral intention; a person with a higher income level seemed to have more willingness to do something advanced like energy-saving intention (Liu, Wang, Wei, Chi, Ma, \& Jian 2020). Other than that, the source of individual wealth (INCS) and INCL influenced someone's decision-making process and determined the behavior (Durham, Manly, \& Ritsema, 2014).

In this current study, the authors tried to posit behavioral intention from two types of young Indonesian generations: generation Y (GENY) and Z (GENZ). Back to this study's background, those two generations are very potential to the national economy through their participation and domination in the stock market. Therefore, the authors tried to do the knowledge development in this preliminary study to test and compare those two generations' perceptive variables on SII. Those then would be moderated by eight categories of demographic characteristics so that the level of someone's investment intention could be measured more broadly and accurately. Figure 4 describes this study's conceptual model framework.

\section{Research Method}

In this study, the unit of analysis target was individuals who belonged to generation $Y$ and $\mathrm{Z}$ in Indonesia, were eligible to invest in the Indonesia stock market, and either had been or had not been participated in the market before. The respondents were sampled based on the demographic characteristics: educational level, occupation, income source, income level, investment experience, and had or never had exposure to financial literacy. In collecting data, a survey using a questionnaire method was prepared to collect respondents' answers from March 2020 to April 2020. This survey method was considered due to its benefits in solving several constraints like time, place, and condition for each respondent. Moreover, the questionnaires were distributed voluntarily to acceptable respondents and provided questions regarding demographic characteristics with clear options and elaborative questions about TPB on stock 
investment intention. It is just like what has already been done by Lai (2019), Phan and Zhou (2014), and Keller and Siegrist (Keller \& Siegrist, 2006). Those TPB elaborations toward stock investment intention are very specific and straight forward in describing how an individual investor sees stock investment.

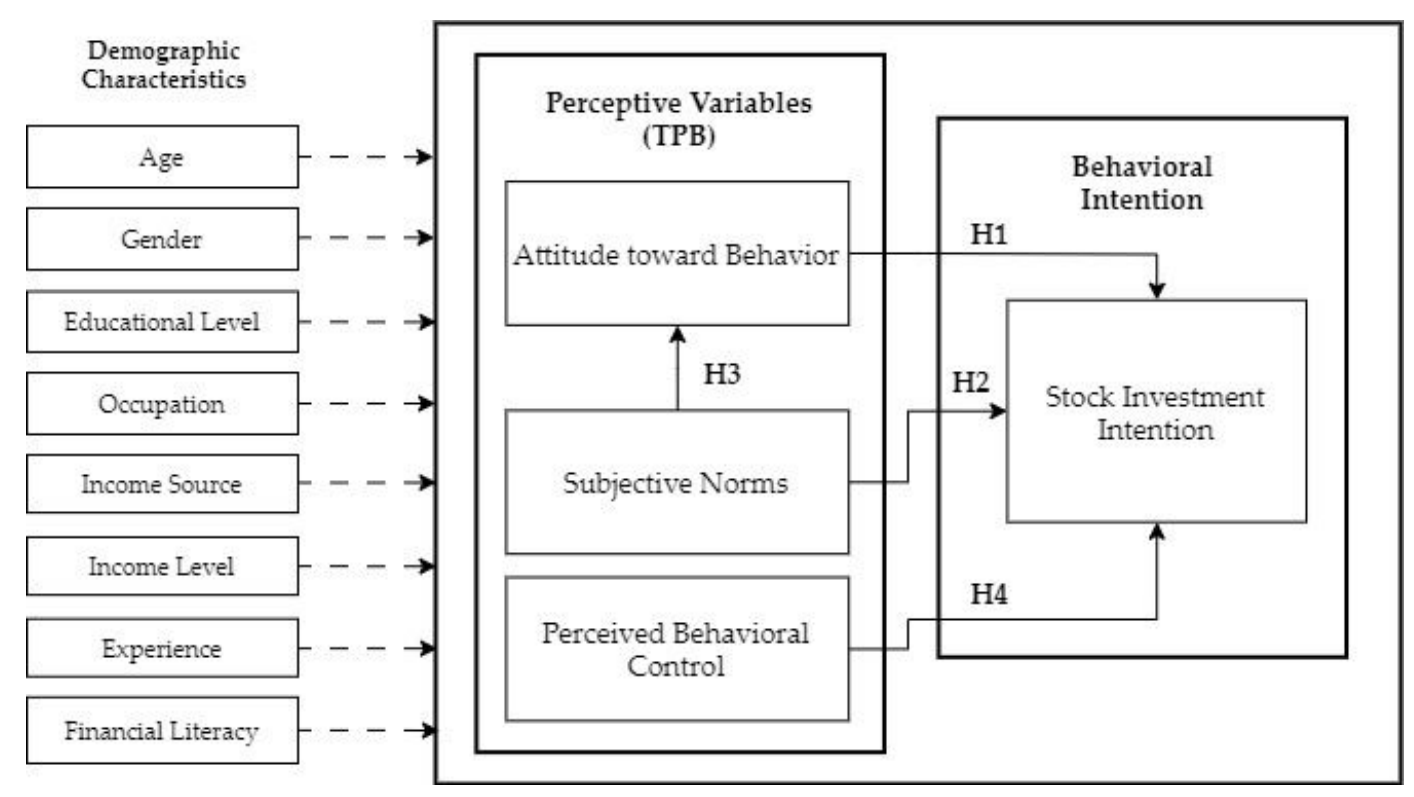

Figure 4 Conceptual Framework

The authors followed two guidelines from Fink (2003) cited in Saunders, Lewis, and Thronhill (2009) and Roscoe (1975) in collecting data. The minimum sample required for a pilot study or preliminary study is 10 (Saunders et al., 2009). On the other one, if the sample will be divided into several parts (male or female and students or employees), the minimum sample size needed is 30 samples for each section (Roscoe, 1975). As a result, 64 responses were collected and screened. Although it was relatively small, it was sufficient in conducting a preliminary study. Every response was used since none of them showed insufficient nor irrelevant information, or in other words, the authors used 100 percent responses for data analysis.

This preliminary study analyzed TPB proxies on Stock Investment Intention with eight demographic characteristics as moderating variables: 1) AGE, 2) GDER, 3) EDU, 4) OCUP, 5) INCL, 6) INCS, 7) EXP, and 8) FLIT. Investment intention was proposed to be the dependent variable used in this study. Investment intention was represented by the intention to invest in the stock market from young generations in Indonesia. The questionnaire was started by addressing the research purposes and another administration aspect like instruction confidentiality. Besides, demographic characteristics questions were needed to provide respondents' information. Then, respondents were asked to rate their agreement or disagreement with the intentions to plan and invest in the stock market continuously through cognitive proxies of TPB. Moreover, the rate applied six-points (1-6) of the Likert scale, in which one indicated 
"strongly disagree", and six indicated "strongly agree". Questions within this research's questionnaire were modified from prior studies and were showed in Table 1.

Table 1 Assessment of Measurement Properties

Constructs and Items

Attitude toward Behavior (ATB)

I think that investing in the stock market can enhance the financial knowledge of individuals (ATB1).

I think that stock investment is meaningful (ATB2).

(1) = Strongly

I think that it is wise for me to engage in stock investment (ATB3).

I think that engaging with stock investment is interesting (ATB4).

disagree to (6)

= Strongly

I think that stock investment is a good idea (ATB5).

Subjective Norm (SN)

I will participate in stock investment if my spouse thinks it is useful (SN1).

I will participate in stock investment if my family approves it (SN2).

I will participate in stock investment if my colleagues do (SN3).

I will participate in stock investment if I have proven friend success on it (SN4).

(1) = Strongly disagree to (6)

I will participate in stock investment if the government encourages it = Strongly (SN5).

agree

I will participate in stock investment if a famous public figure encourages it (SN6).

Perceived Behavioral Control (PBC)

I have enough money for stock investment (PBC1).

I have enough energy for stock investment (PBC2).

I have enough information for stock investment (PBC3).

(1) = Strongly

I have enough time for stock investment (PBC4).

disagree to (6)

I have enough knowledge to overcome obstacles or problems while

= Strongly

engaging in stock investment (PBC5).

Stock Investment Intention (SII)

I intend to engage in stock investment in the near future (SII1).

I expect that I will engage in stock investment activities in the near future

(SII2).

I can stand the inconvenience caused by stock investment (SII3).

I will recommend others to invest in the stock market (SII4).

How much time do you need to spend before engaging in stock investment

(SII5)?

agree

(1) = Strongly

disagree to (6)

= Strongly

agree

(1) = No time at all to $(6)=$ Very much time

The listed questions below were adopted from several studies and adjusted by the authors. Some of these questions in Table 1 were already filtered based on item loadings' value after several evaluations regarding item reliability, internal consistency, and discriminant validity (Bagozzi \& Yi, 1988; Barclay, Thompson, \& Higgins, 1995; Nunnally \& Bernstein, 1994). For example, the evaluation of model measurement was conducted by Fornell and Larcker (1981). The acceptable indicator can be used if it has a loading value higher than 0.6 (Ağan, Kuzey, Acar, \& Açıkgoz, 2016). 


\author{
Nugraha \& Rahadi \\ Analysis of Young Generations toward Stock Investment Intention: ...
}

Data analysis was carried out in accordance with the partial least square structural equation model (PLS-SEM), supported by SmartPLS 3 software. PLS-SEM is often used in management and information system, but in the area of banking and finance, specifically in behavioral finance, it also provides a robust analysis (Avkiran \& Ringle, 2018). Moreover, Monecko and Lelsch found PLS-SEM to have fewer requirements on residual distributions, measuring scales, and sample-sized compared with the covariance-based SEM (COV-SEM) (Monecke \& Leisch, 2012). In short, PLS-SEM was considered suitable to be used in analyzing the model framework proposed by the author. Therefore, the data analysis process was conducted within two steps: (1) the authors evaluated the model by analyzing item reliability, internal consistency, and research instrument discriminant validity using confirmatory factor analysis (CFA). (2) The authors conducted a structural model analysis to check the model and test the hypothesis.

To assess model fit, this preliminary study used Goodness of Fit (GoF). GoF value is ranged from 0 to 1 and is obtained from the square root of the average communalities index multiplied by the average value of the R square of the model (Lo et al., 2005). Greater value means that the model is well-performed to validate the combined performance of the measurement model and the structural model. Moreover, to assess the moderating variables and conduct group comparison, the authors utilized Partial Least-Squares Multi-Group Analysis (PLS-MGA). Each moderating variable was elaborated into two groups that considerably represented the sample.

\title{
Result and Discussion
}

Respondents' demographic profiles obtained in this research paper were summarized in Table 2. Among the analyzed 64 responses, $27.6 \%$ of respondents were classified in the age group of $15-20$ years old, which belonged to GENZ based on literature, age group of $20-25$ dominated with $67.2 \%$, and $5.2 \%$ were $25-35$ years old. Respondents were equally divided between male and female. A total of $55.2 \%$ of respondents declared if they had a bachelor's degree as their educational background. Meanwhile, $29.3 \%$ chose a senior high school, $8.6 \%$ for diploma, and $6.9 \%$ had a master's degree. Most respondents were students with $50 \%$, an employee with $36.2 \%$ in second place, followed by professional (3.4\%), civil servants $(5.2 \%)$, and other occupations (5.2\%). Therefore, only $31 \%$ of respondents had investment experience, and the rest of $69 \%$ of respondents had not participated in any investment activities. The percentage was strengthened by the fact if most of the respondents (62.1\%) never had a financial class or lacked financial literacy. 
Table 2 Sample Characteristics' Description

\begin{tabular}{|c|c|c|}
\hline Characteristics & Frequency & $\%$ \\
\hline \multicolumn{3}{|l|}{ Age } \\
\hline $15-20$ years old & 16 & 25.00 \\
\hline $20-25$ years old & 45 & 70.31 \\
\hline $25-35$ years old & 3 & 4.69 \\
\hline \multicolumn{3}{|l|}{ Gender } \\
\hline Male & 30 & 46.87 \\
\hline Female & 34 & 53.13 \\
\hline \multicolumn{3}{|l|}{ Educational Level } \\
\hline Senior High Schools & 17 & 26.56 \\
\hline Diploma & 6 & 9.38 \\
\hline Bachelor's degree & 37 & 57.81 \\
\hline Master's degree & 4 & 6.25 \\
\hline \multicolumn{3}{|l|}{ Occupation } \\
\hline Student & 30 & 46.87 \\
\hline Employee & 24 & 37.50 \\
\hline Professional & 3 & 4.69 \\
\hline Civil Servants & 3 & 4.69 \\
\hline Other Occupation & 4 & 6.25 \\
\hline \multicolumn{3}{|l|}{ Income Source } \\
\hline Monthly Salary & 31 & 48.44 \\
\hline Business Profit & 6 & 9.38 \\
\hline Project Payment & 6 & 9.38 \\
\hline Investment & 8 & 12.5 \\
\hline Parents & 28 & 43.75 \\
\hline Other Sources & 3 & 4.69 \\
\hline \multicolumn{3}{|l|}{ Income Level } \\
\hline < IDR 3 Million & 26 & 40.63 \\
\hline IDR 3 Million - IDR 6 Million & 25 & 39.06 \\
\hline IDR 6 Million - IDR 10 Million & 8 & 12.50 \\
\hline > IDR 10 Million & 5 & 7.81 \\
\hline \multicolumn{3}{|l|}{ Investment Experience } \\
\hline Yes & 21 & 32.81 \\
\hline No & 43 & 67.19 \\
\hline \multicolumn{3}{|l|}{ Financial Literacy } \\
\hline Yes & 26 & 40.62 \\
\hline No & 38 & 59.38 \\
\hline
\end{tabular}

By utilizing CFA for measuring the model, the authors evaluated the model fit based on three analyses: (1) item reliability, (2) internal consistency, and (3) discriminant validity. The item reliability was examined based on item loadings; for instance, correlations of the items towards the respective construct. According to Lai, if an object's loading value is more significant than 0.6 , it shows that the indicator reliability is accepted (Ağan et al., 2016; Lai, 2019). Therefore, the authors dropped four items from several constructs due to their values of loading lower than the recommended value, namely 0.6: SN (SN1 \& SN2), PBC (PBC4), and SII (SII5). Seventeen indicators' item loadings that have been deemed adequate are summarized in Table 3. 
To provide strong evidence of the measurement model, the authors attached the result of internal consistencies from the latent constructs. To check internal consistency, Cronbach's alpha values, the composite reliability (CR), and the average variance extracted (AVE) of each construct can be monitored (Nunnally \& Bernstein, 1994). The Cronbach's alpha values and CR threshold should be greater than 0.7, while AVE needs to be above 0.5 (Fornell \& Larcker, 1981). Table 3 displays that the Cronbach's alpha values and $C R$ of all constructs used within this study were exceeded 0.8 , and it indicated the scale's reliability (Hair, 2011). Moreover, the AVE value of all constructs exceeded the recommended threshold of 0.5 , and it signified that all constructs within this study had adequate convergent validity.

Table 3 Summary of Measurement Model Analysis

\begin{tabular}{|c|c|c|c|c|}
\hline Constructs/Items & Cronbach's Alpha & Loadings & CR & AVE \\
\hline Attitude toward Behavior (ATB) & 0.888 & & 0.890 & 0.619 \\
\hline ATB1 & & 0.707 & & \\
\hline ATB2 & & 0.709 & & \\
\hline ATB3 & & 0.814 & & \\
\hline ATB4 & & 0.850 & & \\
\hline ATB5 & & 0.840 & & \\
\hline Subjective Norm (SN) & 0.853 & & 0.856 & 0.607 \\
\hline SN3 & & 0.603 & & \\
\hline SN4 & & 0.666 & & \\
\hline SN5 & & 0.785 & & \\
\hline SN6 & & 1.002 & & \\
\hline Perceived Behavioral Control (PBC) & 0.804 & & 0.801 & 0.503 \\
\hline PBC1 & & 0.778 & & \\
\hline PBC2 & & 0.737 & & \\
\hline PBC3 & & 0.627 & & \\
\hline PBC5 & & 0.687 & & \\
\hline Stock Investment Intention (SII) & 0.864 & & 0.862 & 0.617 \\
\hline SII1 & & 0.840 & & \\
\hline SII2 & & 0.625 & & \\
\hline SII3 & & 0.650 & & \\
\hline SII4 & & 0.974 & & \\
\hline
\end{tabular}

Note: This table shows the loadings of constructs' items, Cronbach's alpha values, CR, and AVE. A construct item with a loading value greater than 0.6 indicates that the item reliability is accepted. The rest of the items not stated above were eliminated due to does not pass the threshold. Then, a construct with CR values above 0.7 means the internal consistency is satisfactory, and an AVE value higher than 0.5 means all constructs within this study have adequate convergent validity.

Finished with item reliability and internal consistency, the researchers proceed to analyze all constructs' discriminant validity. Discriminant validity of constructs is indicated if the squared root of AVE for each construct is higher than its correlations with other constructs (Fornell \& Larcker, 1981). In other words, discriminant validity gives insight into the extent to which a construct is different from other constructs (Bagozzi \& Yi, 1988; Barclay et al., 1995; Nunnally \& Bernstein, 1994). Table 4 presents that all diagonal values (the squared root of AVE values) were higher than non-diagonal values (correlations of a construct with others). It signified that the discriminant validity 
of all constructs was proved adequate. In short, the measurement model applied in this study had sufficient reliability, convergent validity, and discriminant validity.

Table 4 Summary of Measurement Model Analysis

\begin{tabular}{cccc|c|}
\hline Constructs & ATB & SN & PBC & SII \\
\hline ATB & 0.787 & & & \\
SN & 0.453 & 0.779 & & \\
PBC & 0.578 & 0.576 & 0.709 & \\
SII & 0.783 & 0.410 & 0.359 & 0.785 \\
\hline
\end{tabular}

Note: Bolded diagonal values are the AVE's square root, and the non-diagonal values are correlations of a construct with other constructs.

Referring to the structural model analysis results conducted as a part of data analysis in this study, not all structural regression coefficients within this research model framework were significant (refer to Table 5). It utilized the bootstrapping method with 1000 resamples to elaborate on the significance level among constructs in the structural model. As shown in Table 4 and explained in Figure 5 (The thickness level on the arrow lines explain how strong the relationship is the path coefficient itself, and thick lines present strong and thin for small path coefficient), not all hypothesis was supported by current empirical data obtained.

Table 5 Results of the Structural Model Analysis

\begin{tabular}{lccccc}
\hline & Hypothesis & Path Coefficient & $t$-Value & $p$-Value & Conclusion \\
\hline H1 & ATB $\rightarrow$ SII & 0.837 & 6.934 & $0.0000^{* * *}$ & Supported \\
H2 & SN $\rightarrow$ SII & 0.154 & 0.856 & 0.3924 & Not Supported \\
H3 & PBC $\rightarrow$ SII & -0.213 & 1.083 & 0.2789 & Not Supported \\
H4 & SN $\rightarrow$ ATB & 0.453 & 2.770 & $0.0050^{*}$ & Supported \\
\hline
\end{tabular}

Note: Path significance: ${ }^{* * *} \mathrm{p}<.001 ;{ }^{* *} \mathrm{p}<.01 ;{ }^{*} \mathrm{p}<.05$

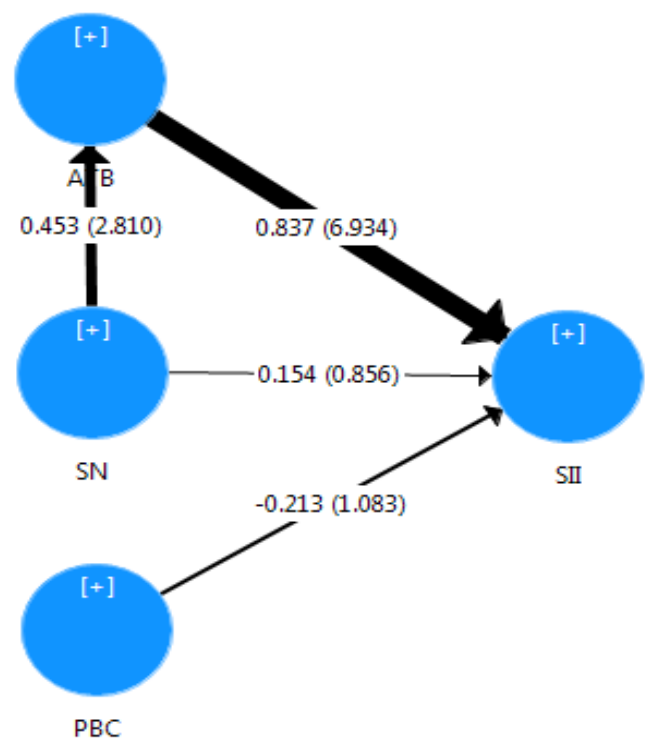

Figure 5 Path Coefficient and t-Test Result of Structural Model 


\author{
Nugraha \& Rahadi \\ Analysis of Young Generations toward Stock Investment Intention: ...
}

Only ATB was significant and had a positive effect on SII. All investment activities were determined and guided by the attitude; the intention to invest was higher if the attitude was categorized as positive. This result is in line with several prior literature findings, like Lai (2019) and Phan and Zhou (2014). Moreover, the empirical result also showed that SN was insignificant on SII and PBC to SII empirically. These findings are not in line with prior literature conducted by Lai (2019) and Phan and Zhou (2014). Meanwhile, SN was found positively and significantly influenced ATB. This result is consistent with previous studies (Chang, 1998; Fishbein \& Ajzen, 1975; Han et al., 2010; Lai, 2019; Phan \& Zhou, 2014; Ryu \& Jang, 2016).

Knowing ATB was found to have a significant positive influence on SIl, it was empirically proved that the young Indonesian generation thought if engaging in stock investment could enhance their financial knowledge and it was meaningful, a wise choice, interesting, and a good idea. Therefore, all stakeholders can put more attention to these two generations' attitude factors. For instance, IDX or Securities Firms can develop one smart mobile application as a stock investment platform connected to the market and having extra features like an online investor forum, online consultation for investment advisory, and online investment and trading workshop. In short, those can provide more knowledge to the potential future investor. Moreover, all stakeholders can also develop every stock investment activity's infrastructure to improve the fair-trading mechanism. The development will increase young generations' intention to invest as it will lead to better efficiency, which is close to investor constraints in making the stock investment, such as information availability, time spending in investing and trading procedure, and risk probability.

The findings regarding SN were found insignificant on SII; implicitly stated that young Indonesian generations would not be influenced to start stock investing even though key persons or organizations encourage them. It indicated that all stakeholders involved could not utilize key persons or organizations and mainstream media to share related information. However, the findings still stated that SN positively and significantly affected ATB. Thus, the authors suggest that stakeholders still need to try any potential social pressure to encourage these young generations to perform particular attitudes related to stock investment. Hence, it may lead to intention in the end. For instance, attractive socialization in social media from a famous and reputable public figure with a gaming approach or interactive video blog can be more influential, as known that these generations are close to the digital environment and the internet world.

Limited data obtained and analyzed did not affect the results, including the Goodness of Fit (GoF), which validated the measurement model's combined performance and structural model. GoF values range from 0 to 1 with interpretations of values: 0.1 (small Gof), 0.25 (moderate GoF), and 0.36 (large GoF) (Wetzels, Odekerken-Schröder, \& Oppen 2009). Referring to a small amount of data obtained within this study, the GoF value was 0.28 , equal to the threshold value of 0.28 for the moderate model. In other words, the model from this preliminary study could perform but not too well enough to validate the combined performance of the measurement model and the structural model. 
The selected moderating variables within this study were analyzed by utilizing Partial Least Squares Multi-Group Analysis (PLS-MGA), a suitable approach for group comparison in research (Sarstedt, Henseler, \& Ringle, 2011). Several of this research's moderating variables were ever tested in prior literature, and differences were exposed between a group to another. For instance, gender as a moderating variable proved that there were differences in perception between male and female (Gilligan, 1993), communication (Tannen, 1990), and even in behavioral intention in investing (Lai, 2019; Phan \& Zhou, 2014). Therefore, this study is the first that elaborates on eight moderating variables to find whether there are differences among each group regarding the intention to make a stock investment in an emerging market. However, the sample number is critical in terms of result-wise and important for data grouping into side $A$ and side B. In this context, following Moores and Chang, the authors decided to recategorize several sub-samples in considering the interpretable categories and compensation for the unequal response obtained (Moores \& Chang, 2006).

The authors determined two groups for each selected moderating variable, which considerably represented the sample. For AGE, the authors grouped the respondents to GENZ and GENY. Respondents below 20 years old belonged to GENZ, then the rest of respondents above 20 years old were categorized into GENY. In terms of GDER, respondents were divided into male and female. On the EDU side, the authors compared the responses based on non-uni for those who were still or have passed the pre-university level of education and Uni for those who had already or were still pursuing degrees from the university. In the context of OCUP, respondents were grouped into student and non-student. Parent and non-parent were two groups to assess the INCS. For INCL, authors set below IDR 6 Million and above IDR 6 Million as the two groups in examining the responses. Moreover, for the last two moderating variables, EXP and FLIT, the respondents were grouped based on their responses, yes and no.

The PLS-MGA results summarized in Table 6 show that only EDU was found to have a moderating role on the model proposed, specifically on the relationship between SN and ATB. The rest of the elements in this group comparison did not have any moderating roles. Thus, for this context, all stakeholders involved need to be concerned with the education level of Indonesian young generations; more specific campaigns or programs can be based on these groups. For example, stakeholders can work together with a reputable public figure on social media to encourage those potential young generations who are still high school students. Interestingly, several of the results are not in line with prior literature. Before, EXP or stock investing experience were found to play significant moderating roles on ATB to SII (Lai, 2019). Besides, GDER: female and male indicated very significant gender-based differences regarding investor stock investment intention in the Vietnamese Stock Market (Phan \& Zhou, 2014). 
Table 6 Results of the Multi-Group Analysis

\begin{tabular}{|c|c|c|c|c|c|}
\hline \multicolumn{6}{|l|}{ AGE } \\
\hline \multirow{2}{*}{\multicolumn{2}{|c|}{ Hypothesis }} & \multicolumn{2}{|c|}{ Standardized Path Coefficients } & \multirow[t]{2}{*}{ Difference } & \multirow[t]{2}{*}{$p$-Value } \\
\hline & & GENZ & GENY & & \\
\hline H1 & ATB $\rightarrow$ SII & 0.519 & 0.655 & 0.136 & 0.664 \\
\hline $\mathrm{H} 2$ & $\mathrm{SN} \rightarrow \mathrm{SII}$ & 0.190 & 0.286 & 0.096 & 0.459 \\
\hline H3 & $\mathrm{PBC} \rightarrow \mathrm{SII}$ & 0.141 & -0.104 & 0.245 & 0.178 \\
\hline H4 & $\mathrm{SN} \rightarrow \mathrm{ATB}$ & 0.669 & 0.454 & 0.215 & 0.150 \\
\hline \multicolumn{6}{|c|}{ GDER } \\
\hline \multirow{2}{*}{\multicolumn{2}{|c|}{ Hypothesis }} & \multicolumn{2}{|c|}{ Standardized Path Coefficients } & Difference & $p$-Value \\
\hline & & Male & Female & & \\
\hline H1 & ATB $\rightarrow$ SII & 0.754 & 0.657 & 0.097 & 0.338 \\
\hline $\mathrm{H} 2$ & $\mathrm{SN} \rightarrow \mathrm{SII}$ & 0.158 & -0.046 & 0.204 & 0.222 \\
\hline H3 & $\mathrm{PBC} \rightarrow \mathrm{SII}$ & -0.198 & 0.188 & 0.386 & 0.902 \\
\hline H4 & $\mathrm{SN} \rightarrow \mathrm{ATB}$ & 0.613 & 0.281 & 0.332 & 0.163 \\
\hline \multicolumn{6}{|l|}{ EDU } \\
\hline \multirow{2}{*}{\multicolumn{2}{|c|}{ Hypothesis }} & \multicolumn{2}{|c|}{ Standardized Path Coefficients } & Difference & $p$-Value \\
\hline & & Non-Uni & Uni & & \\
\hline H1 & ATB $\rightarrow$ SII & 2.933 & 0.679 & 0.319 & 0.138 \\
\hline $\mathrm{H} 2$ & $\mathrm{SN} \rightarrow \mathrm{SII}$ & -2.451 & 0.296 & 0.290 & 0.759 \\
\hline H3 & $\mathrm{PBC} \rightarrow \mathrm{SII}$ & 0.476 & -0.228 & 0.095 & 0.410 \\
\hline H4 & $\mathrm{SN} \rightarrow \mathrm{ATB}$ & 0.975 & 0.162 & 0.716 & $0.000 * * *$ \\
\hline \multicolumn{6}{|c|}{ OCUP } \\
\hline \multirow{2}{*}{\multicolumn{2}{|c|}{ Hypothesis }} & \multicolumn{2}{|c|}{ Standardized Path Coefficients } & Difference & $p$-Value \\
\hline & & Student & Non-Student & & \\
\hline H1 & ATB $\rightarrow$ SII & 0.761 & 0.649 & 0.112 & 0.666 \\
\hline $\mathrm{H} 2$ & $\mathrm{SN} \rightarrow \mathrm{SII}$ & 0.237 & 0.132 & 0.105 & 0.649 \\
\hline H3 & $\mathrm{PBC} \rightarrow \mathrm{SII}$ & -0.231 & -0.003 & 0.228 & 0.203 \\
\hline H4 & $\mathrm{SN} \rightarrow \mathrm{ATB}$ & 0.467 & 0.348 & 0.119 & 0.686 \\
\hline \multicolumn{6}{|l|}{ INCS } \\
\hline & Hypothesis & \multicolumn{2}{|c|}{ Standardized Path Coefficients } & Difference & $p$-Value \\
\hline & & Parent & Non-Parents & & \\
\hline H1 & ATB $\rightarrow$ SII & 0.554 & 0.793 & 0.240 & 0.170 \\
\hline $\mathrm{H} 2$ & $\mathrm{SN} \rightarrow \mathrm{SII}$ & 0.127 & 0.250 & 0.123 & 0.330 \\
\hline H3 & $\mathrm{PBC} \rightarrow \mathrm{SII}$ & 0.148 & -0.239 & 0.378 & 0.945 \\
\hline H4 & $\mathrm{SN} \rightarrow \mathrm{ATB}$ & 0.281 & 0.551 & 0.271 & 0.330 \\
\hline \multicolumn{6}{|l|}{ INCL } \\
\hline & Hypothesis & \multicolumn{2}{|c|}{ Standardized Path Coefficients } & Difference & $p$-Value \\
\hline & & $<6$ Million & > 6 Million & & \\
\hline H1 & ATB $\rightarrow$ SII & 0.547 & 0.731 & 0.184 & 0.754 \\
\hline $\mathrm{H} 2$ & $\mathrm{SN} \rightarrow \mathrm{SII}$ & 0.012 & 0.288 & 0.276 & 0.813 \\
\hline H3 & $\mathrm{PBC} \rightarrow \mathrm{SII}$ & 0.160 & -0.151 & 0.311 & 0.102 \\
\hline $\mathrm{H} 4$ & $\mathrm{SN} \rightarrow \mathrm{ATB}$ & 0.504 & 0.569 & 0.065 & 0.529 \\
\hline EXP & & & & & \\
\hline
\end{tabular}


Nugraha \& Rahadi

Analysis of Young Generations toward Stock Investment Intention: ...

Table 6 Results of the Multi-Group Analysis (cont')

\begin{tabular}{|c|c|c|c|c|c|}
\hline \multicolumn{6}{|l|}{ AGE } \\
\hline & Hypothesis & \multicolumn{2}{|c|}{ Standardized Path Coefficients } & Difference & $p$-Value \\
\hline & & Yes & No & & \\
\hline H1 & ATB $\rightarrow$ SII & 0.784 & 0.619 & 0.165 & 0.246 \\
\hline $\mathrm{H} 2$ & $\mathrm{SN} \rightarrow \mathrm{SII}$ & 0.385 & 0.072 & 0.313 & 0.147 \\
\hline H3 & $\mathrm{PBC} \rightarrow \mathrm{SII}$ & -0.236 & 0.059 & 0.295 & 0.796 \\
\hline H4 & $\mathrm{SN} \rightarrow \mathrm{ATB}$ & 0.445 & 0.421 & 0.024 & 0.457 \\
\hline \multicolumn{6}{|l|}{ FLIT } \\
\hline & Hypothesis & \multicolumn{2}{|c|}{ Standardized Path Coefficients } & Difference & $p$-Value \\
\hline & & Yes & No & & \\
\hline H1 & ATB $\rightarrow$ SII & 0.810 & 0.658 & 0.151 & 0.212 \\
\hline $\mathrm{H} 2$ & $\mathrm{SN} \rightarrow \mathrm{SII}$ & 0.157 & 0.221 & 0.065 & 0.593 \\
\hline H3 & $\mathrm{PBC} \rightarrow \mathrm{SII}$ & -0.258 & -0.010 & 0.248 & 0.845 \\
\hline H4 & $\mathrm{SN} \rightarrow \mathrm{ATB}$ & 0.563 & 0.337 & 0.226 & 0.205 \\
\hline
\end{tabular}

Note: This table reports the hypothesis testing results on the moderating variables used within this study. The findings revealed that only EDU was found to have a moderating role on the model proposed, specifically on SN and ATB's relationship. The level of significance (two-tailed test): $* * * \mathrm{p}<0.001$.

\section{Conclusion}

This study was intended to provide empirical evidence and theoretical analysis in the context of preliminary study regarding how individual's perceptive factors influence behavioral intention and lead them to do such stock investment activities, including demographic characteristics that play a moderating role in the relationship. The current study obtained a data sample from 64 young Indonesian generations with various demographic characteristics, including those with and without investment experiences and those who ever and never had any financial literacy class. Generation $Y$ and $Z$ were chosen due to their potential to move the national economy of an emerging country like Indonesia in the future to better directions. However, in filling the survey, these young generations might have quite enough constrained that influenced the response. Those constraints made good sense since most respondents of this study were found still depending on their parents or in the condition of starting their career path. Thus, the investment could not be their top list priority. However, the authors consider that this condition is the best time to prepare young Indonesian generations.

Other than that, this preliminary study also showed potential facts about validations regarding the theory of planned applicability in Indonesia in explaining individual or specifically young generations' intention to enter the stock market and start investing, including the perspective of emerging market and the specific elaborations of individual profiles as respondents. The findings revealed that not all TPB proxies significantly influenced the individual's stock investment intention in Indonesia. Thus, this preliminary study's result is contrary to what has been found in other countries or different markets (Elliott \& Ainsworth, 2012; Lai, 2019; Phan \& Zhou, 2014). This theory's applicability and current facts of these two generations will be useful for all 
stakeholders involved in Indonesia's investment activities to develop the system and products itself. However, further research regarding this topic will be more interesting, knowing that this study is preliminary only with small sample size.

If these insights found can be a new consideration to all stakeholders involved, those stakeholders need to validate further since all these findings were limited to preliminary study situation; hence, the result could be different in more comprehensive research. However, creating a campaign or program to socialize stock investment will help give a better understanding of Indonesian young generations' perspective regarding stock investment; thus, the probability of investor growth numbers can be more significant. All of the preliminary study findings can help companies that want to maximize their funding source from the stock market. They can take this as an initiative to generate a new sustainable strategy approach and make young generations familiar with them; hence, the sense of belongings with the firm enhanced and can become more potential investors for the firm.

Although this study successfully provides several exciting information and insight concerning factors influencing young generations' intention about stock investment and the theory of planned behavior applicability in Indonesia in a preliminary context, this study still has limitations. First, an investigation of stock investment intention that specifically analyzes young generations in Indonesia is arguably new. Therefore, the sample was restricted to young generations divided into generation $Y$ and $Z$ from Indonesia only. Second, this study focused on the fundamental implementation of TPB; hence, the individual behavioral intention analysis was limited to TPB proxies. Third, since the online questionnaire was used to collect the data, the findings were limited, depending on the respondents' answers regarding the issue. Conventional distributed questionnaires are still do-able to be done by future researchers. Appropriate place and time must be considered; in this context, a place like the country's capital city may have more various responses and types of respondents. A place like the capital city becomes a melting-pot for many people with different backgrounds and characters. From these limitations, the authors recommend that future researchers continue the analysis by adding additional constructs like personality traits, psychological factors, or involving several marketing approaches to assess young generations' intention on stock investing. Another investment analysis was also recommended; even a comparison of stock and other instruments is exciting to be investigated. Moreover, future researchers should also consider a bigger sample size to get better and more robust findings.

\section{References}

Ağan, Y., Kuzey, C., Acar, M. F., \& Açıkgöz, A. (2016). The relationships between corporate social responsibility, environmental supplier development, and firm performance. Journal of Cleaner Production, 112(3), 1872-1881. https://doi.org/10.1016/i.jclepro.2014.08.090

Ajzen, I. (1991). The theory of planned behavior. Organizational Behavior and Human Decision Processes, 50(2), 179-211. https://doi.org/10.1016/0749-5978(91)90020-T 
Akhtar, F., \& Das, N. (2019). Predictors of investment intention in Indian stock markets: Extending the theory of planned behaviour. International Journal of Bank. Marketing, 37(1), 97-119. https://doi.org/10.1108/IJBM-08-2017-0167

Avkiran, N. K., \& Ringle, C. M. (2018). Partial Least Squares structural equation modeling: Recent advances in banking and finance (eds). Springer International Publishing. https://doi.org/10.1007/978-3-319-71691-6

Azwar, S. (2013). Sikap manusia: Teori dan pengukurannya (2nd ed.). Yogyakarta: Pustaka Pelajar.

Badan Kependudukan dan Keluarga Berencana Nasional Keluarga Bahagia. (2017). Bonus demografi menyongsong indonesia emas 2045. Retrieved from BKKBN-KB. Available at https://keluargaindonesia.id/infografik/bonus-demografi-menyongsong-indonesia$\underline{\text { emas-2045 }}$

Bagozzi, R. P., \& Yi, Y. (1988). On the evaluation of structural equation models. Journal of the Academy of Marketing Science, 16(1), 74-94. https://doi.org/10.1007/BF02723327

Barber, B. M., \& Odean, T. (2000). Boys will be boys: Gender, overconfidence, and common stock investment. Quarterly Journal of Economics, 1-39. https://papers.ssrn.com/abstract $=219240$

Barberis, N., Shleifer, A., \& Vishny, R. (1998). A model of investor sentiment. Journal of Financial Economics, 49(3), 307-343. https://doi.org/10.1016/S0304-405X(98)00027$\underline{0}$

Barclay, D., Thompson, R., \& Higgins, C. (1995). The Partial Least Squares (PLS) approach to causal modelling: Personal computer use as an illustration. Technology Studies, 2(2), 285-309. Retrieved from https://scholar.google.com/scholar?cluster $=10934427946688273356 \&$ hl=en\&as sd $\underline{\mathrm{t}=2005 \& \text { sciodt }=0,5}$

Birchmore, R., \& Kestle, L. (2011). The XYZ of the living curriculum. Semantic Scholar.

Chang, M. K. (1998). Predicting unethical behavior: a comparison of the theory of reasoned action and the theory of planned behavior. Journal of Business Ethics, 17(16), 18251834. https://doi.org/10.1023/A:1005721401993

Daniel, K., Hirshleifer, D., \& Subrahmanyam, A. (1998). Investor psychology and security market under and overreactions. The Journal of Finance, 53(6), 1839-1885. https://doi.org/10.1111/0022-1082.00077

Durham, Y., Manly, T. S., \& Ritsema, C. (2014). The effects of income source, context, and income level on tax compliance decisions in a dynamic experiment. Journal of Economic Psychology, 40(February), 220-233. https://doi.org/10.1016/i.joep.2012.09.012

East, R. (1993). Investment decisions and the theory of planned behaviour. Journal of Economic Psychology, 14(2), 337-375. https://doi.org/10.1016/0167-4870(93)90006-7

Elliott, M. A., \& Ainsworth, K. (2012). Predicting university undergraduates' binge-drinking behavior: A comparative test of the one- and two-component theories of planned behavior. Addictive Behaviors, 37(1), 92-101. https://doi.org/10.1016/j.addbeh.2011.09.005

Fama, E. F. (1965). The behavior of stock-market prices. The Journal of Business, 38(1), 34-105. https://doi.org/10.1086/294743

Fishbein, M., \& Ajzen, I. (1975). Belief, attitude, intention, and behavior: An introduction to theory and research. Reading, MA: Addison-Wesley.

Fornell, C., \& Larcker, D. F. (1981). Evaluating structural equation models with unobservable variables and measurement error: Journal of Marketing Research, 18(1), 39-50. https://doi.org/10.1177/002224378101800104

Gilligan, C. (1993). In a different voice: Psychological theory and women's development. Cambridge: Harvard University Press. 
Griffith, J., Najand, M., \& Shen, J. (2020). Emotions in the stock market. Journal of Behavioral Finance, 21(1), 42-56. https:// doi.org/10.1080/15427560.2019.1588275

Hair, J. F. (2011). Multivariate data analysis: An overview. In M. Lovric (Ed.). Berlin: Springer.

Han, H., Hsu, L.-T. (Jane), \& Sheu, C. (2010). Application of the theory of planned behavior to green hotel choice: Testing the effect of environmental friendly activities. Tourism Management, 31(3), 325-334. https://doi.org/10.1016/i.tourman.2009.03.013

Jaziri, M., \& Abdelhedi, M. (2018). Islamic occasions and investor sentiment. International Journal of Islamic and Middle Eastern Finance and Management, 11(2), 194-212. https://doi.org/10.1108/IMEFM-08-2017-0225

Keller, C., \& Siegrist, M. (2006). Money attitude typology and stock investment. Journal of Behavioral Finance, 7(2), 88-96. https://doi.org/10.1207/s15427579jpfm0702 3

Kencana, M. R. B. (2019). Mayoritas investor pasar modal Indonesia berumur di bawah 30 tabun. Retrieved from Liputan6.com. Available at https://www.liputan6.com/bisnis/read/3997082/mayoritas-investor-pasar-modalindonesia-berumur-di-bawah-30-tahun

Kiyosaki, R. T., \& Lechter, S. L. (2001). Rich dad poor dad: what the rich teach their kids about money-that the poor and the middle class do not!. New York: Time Warner Audiobooks.

Kustodian Sentral Efek Indonesia. (2020). Jumlah sub rekening efek di C-BEST. Retrieved from KSEI. Available at https://www.ksei.co.id/data/graph/number-of-sub-account-inc-best

Lai, C. (2019). Personality traits and stock investment of individuals. Sustainability, 11(19), 5474. https://doi.org/10.3390/su11195474

Lintner, J. (1965). Security prices, risk, and maximal gains from diversification. The Journal of Finance, 20(4), 587-615. https://doi.org/10.1111/j.1540-6261.1965.tb02930.x

Liu, X., Wang, Q., Wei, H.-H., Chi, H.-L., Ma, Y., \& Jian, I. Y. (2020). Psychological and demographic factors affecting household energy-saving intentions: A tpb-based study in northwest china. Sustainability, 12(3), 836. https://doi.org/10.3390/su12030836

Lo, A. W., Repin, D. V., \& Steenbarger, B. N. (2005). Fear and greed in financial markets: A clinical study of day-traders. Social Science Research Network, 1-27. https://papers.ssrn.com/abstract $=697168$

Luky, M. R. (2016). Minat berinvestasi di pasar modal: Aplikasi theory of planned behavior serta persepsi berinvestasi di kalangan mahasiswa. Jurnal Ilmiah Mahasiswa FEB, 4(2), 20-40. https://jimfeb.ub.ac.id/index.php/jimfeb/article/view/3245

Mahastanti, L. A., \& Hariady, E. (2014). Determining the factors which affect the stock investment decisions of potential female investors in Indonesia. International Journal of Process Management and Benchmarking, 4(2), 186-197. Retrieved from https://ris.uksw.edu/download/jurnal/kode/J00716

Mannheim, K. (1928). The problem of generations. Essays on the Sociology of Knowledge, 276 320.

Mardiyati, U., \& Rosalina, A. (2017). Analisis pengaruh nilai tukar, tingkat suku bunga dan inflasi terhadap indeks harga saham. Studi kasus pada perusahaan properti yang terdaftar di Bursa Efek Indonesia. Jurnal Riset Manajemen Sains Indonesia, 4(1), 1-15. http://journal.unj.ac.id/unj/index.php/irmsi/article/view/775

Metawa, N., Hassan, M. K., Metawa, S., \& Safa, M. F. (2019). Impact of behavioral factors on investors' financial decisions: Case of the Egyptian stock market. International Journal of Islamic and Middle Eastern Finance and Management, 12(1), 30-55. https://doi.org/10.1108/IMEFM-12-2017-0333 
Monecke, A., \& Leisch, F. (2012). SEMPLS: Structural equation modelling using Partial Least Squares. Journal of Statistical Software, 48(1), 1-32. https://doi.org/10.18637/jss.v048.i03

Moores, T. T., \& Chang, J. C.-J. (2006). Ethical decision making in software piracy: Initial development and test of a four-component model. MIS Quarterly, 30(1), 167-180. JSTOR. https:// doi.org/10.2307/25148722

Morris, M. G., \& Venkatesh, V. (2000). Age differences in technology adoption decisions: Implications for a changing work force. Personnel Psychology, 53(2), 375-403. https://doi.org/10.1111/j.1744-6570.2000.tb00206.x

Nunnally, J., \& Bernstein, I. H. (1994). Psychometric theory. McGraw-Hill Companies: Incorporated.

O'Connor, M. C., \& Paunonen, S. V. (2007). Big five personality predictors of postsecondary academic performance. Personality and Individual Differences, 43(5), 971-990. https://doi.org/10.1016/i.paid.2007.03.017

Octarina, E., Hartoyo, \& Beik, I. S. (2019). Customer purchase intention on sharia mutual fund products: A TPB approach. Journal of Consumer Sciences, 4(1), 37-37. https://doi.org/10.29244/jcs.4.1.37-47

Otoritas Jasa Keuangan. (2019). Getting to know capital market investment gallery, a place where you could have the stocks education and transactions. Retrieved from Otoritas Jasa Keuangan. Available at https://sikapiuangmu.ojk.go.id/FrontEnd/CMS/Article/10381

Panggalih, R. G., \& Baridwan, Z. (2012). Minat individu terhadap penggunaan internet banking: Pendekatan modified theory of planned behavior. Jurnal Ilmiah Mahasiswa FEB, 1(2), 21-40. https://jimfeb.ub.ac.id/index.php/jimfeb/article/view/589

Phan, K. C., \& Zhou, J. (2014). Factors influencing individual investors' behavior: An empirical study of the vietnamese stock market. American Journal of Business and Management, 3(2), 77-94. https://doi.org/10.11634/216796061706527.

Roscoe, J. T. (1975). Fundamental research statistics for the behavioral sciences (2d ed.). New York: Rinehart and Winston.

Ryu, K., \& Jang, S. (Shawn). (2016). Intention to experience local cuisine in a travel destination: The modified theory of reasoned action. Journal of Hospitality \& Tourism Research, 30(4), 507-516. https://doi.org/10.1177/1096348006287163

Saraswati, K. R. A., \& Wirakusuma, M. G. (2018). Pemahaman atas investasi memoderasi pengaruh motivasi dan risiko investasi pada minat berinvestasi. E-Jurnal Akuntansi, 24(2), 1584-1599. https://doi.org/10.24843/EJA.2018.v24.i02.p28

Sari, H., \& Pradana, M. R. A. (2018). Perancangan strategi pemasaran galeri investasi berdasarkan faktor-faktor yang mempengaruhi intensi investor untuk berinvestasi. Jurnal Ilmiah Teknik Industri, 17(2), 158-168. https://doi.org/10.23917/jiti.v17i2.5887

Sari, P., \& Mayasari, I. (2017). Analisis komunikasi pemasaran terpadu pada kampanye yuk nabung saham PT Bursa Efek Indonesia. Thesis. Universitas Gadjah Mada. http://etd.repository.ugm.ac.id/penelitian/detail/128785

Sarstedt, M., Henseler, J., \& Ringle, C. M. (2011). Multigroup analysis in Partial Least Squares (PLS) path modeling: Alternative methods and empirical results. Advances in International Marketing, 22(1), 195-218. https://doi.org/10.1108/s14747979(2011)0000022012

Saunders, M., Lewis, P., \& Thornhill, A. (2009). research methods for business students. Prantice Hall.

Sheeran, P., Trafimow, D., \& Armitage, C. (2003). Predicting behavior from perceived behavioural control: Tests of the accuracy assumption of the theory of planned behaviour. British Journal of Social Psychology, 42(3), 393-410.

https://doi.org/10.1348/014466603322438224 
Situmorang, M., Andreas, \& Natariasari, R. (2015). Pengaruh motivasi terhadap minat berinvestasi di pasar modal dengan pemahaman investasi dan usia sebagai variabel moderate. Jurnal Online Mahasiswa (JOM) Bidang Ilmu Ekonomi, 1(2), 1-18. Retrieved from https://jom.unri.ac.id/index.php/JOMFEKON/article/view/4675

Slameto. (2003). Belajar dan faktor-faktor yang mempengarubinya. Yogyakarta: Rineka Cipta.

Statman, M., Thorley, S., \& Vorkink, K. (2008). Investor overconfidence and trading volume. The Review of Financial Studies, 19(4), 1531-1565. https://doi.org/10.1093/rfs/hhj032

Tannen, D. (1990). You just do not understand: women and men in conversation (6th ed.). New York: Morrow.

Wetzels, M., Odekerken-Schröder, G., \& Oppen, C. V. (2009). Using PLS path modeling for assessing hierarchial construct models: Guidelines and impirical illustration. MIS Quarterly, 33(1), 177-195.

Worldometer. (2020). Indonesia population. Retrieved from Worldometer. Available at https://www.worldometers.info/world-population/indonesia-population/

Yen, S.-H., Chang, Y.-S., \& Wu, M.-C. (2016). Behavioral intention of earnings management: The explanation of agency problem, moral development and theory of planned behavior. NTU Management Review, 26, 107-138.

https://doi.org/10.6226/NTUMR.2016.FEB.R.12028 